\title{
Urban Consumer Behavior On Buying Multi-Products On Shopee Using Technology Acceptance Model (TAM)
}

\author{
Michael Christian ${ }^{1}$, Halim Agung ${ }^{2}$ \\ ${ }^{1}$ Program Studi Manajemen, Universitas Bunda Mulia \\ Jl. Lodan Raya No. 2 Ancol, Jakarta Utara 14430, Indonesia \\ michaelchristianid@gmail.com \\ ${ }^{2}$ Program Studi Bisnis Digital, Universitas Bunda Mulia \\ Jl. Lodan Raya No. 2 Ancol, Jakarta Utara 14430, Indonesia \\ hagung@bundamulia.ac.id \\ *Email corresponding author \\ michaelchristianid@gmail.com
}

Received 5 August 2020, Revised 31 August 2020, Accepted 31 August 2020

\begin{abstract}
People who live in urban areas can be explained as social groups that are sociologically in the middle class, have a productive life, and are part of social change. Shopee as one of the marketplaces in Indonesia always needs to consider the factor of technology usage that allows users to make purchases with a variety of products (multi-product) available. This study aims to analyze the behavior of using Urban Consumer Behavior with the Technology Acceptance Model (TAM) approach. Data analysis using SMART PLS 3.0 involving 163 samples in Jakarta with survey-questionnaire as a method of data collection. The results of this study explain that two hypotheses were accepted and two more hypotheses were rejected. In this case, Shopee's websitelapp usage behavior is influenced by the Ease of Use Factor. Furthermore the Benefit factor is influenced by the Ease of Use factor. On the other hand, usage is not influenced by usage behavior. Then the use is not influenced by the expediency factor. TAM as a classic model in explaining technology adoption in aspects of daily life is still needed to gain more understanding, especially on the characteristics of various or different samples.

Keywords: Ease, Usability, Behavior, Urban
\end{abstract}

\begin{abstract}
Abstrak - Masyarakat yang tinggal di wilayah perkotaan dapat dijelaskan sebagai kelompok sosial yang secara perspektif sosiologis berada pada kelas menengah, memiliki kehidupan yang produktif, dan menjadi bagian dari perubahan sosial. Shopee sebagai salah satu marketplace di Indonesia selalu mempertimbangkan faktor penggunaan teknologi yang memungkinkan pengguna untuk melakukan pembelian dengan ragam produk (multi produk) yang tersedia. Penelitian ini bertujuan untuk menganalisis perilaku penggunaan Urban Consumer Behavior dengan pendekatan Technology Acceptance Model (TAM). Analisis data menggunakan SMART PLS 3.0 dengan melibatkan 163 sampel di Jakarta dengan survey-kuesioner sebagai metode pengumpulan data. Hasil penelitian ini menjelaskan bahwa dua hipotesis diterima dan dua hipotesis lagi ditolak. Dalam hal ini, perilaku penggunaan situs/aplikasi Shopee dipengaruhi oleh Faktor Kemudahan Penggunaan. Selanjutnya faktor Kemanfaatan dipengaruhi faktor Kemudahan Penggunaan. Di sisi berbeda Penggunan tidak dipengaruhi Perilaku penggunaan. Kemudian Penggunaan tidak dipengaruhi oleh faktor kemanfaatan. TAM sebagai model klasik dalam menjelaskan adopsi teknologi dalam aspek kehidupan sehari-hari masih diperlukan untuk mendapatkan pemahaman lebih khususnya pada karakteristik sampel yang beragam ataupun berbeda.
\end{abstract}

Kata Kunci: Kemudahan Penggunaan, Kemanfaatan, Perilaku, Urban 


\section{INTRODUCTION}

Modern urban groups have a variety of considerations in making purchasing decisions, such as the function of the product purchased, the benefits that the product can provide to its users, to the reason the product purchased can provide benefits or benefits for the buyer (Singh, Kumar, Goel, \& Chawla, 2014). Desires and opinions about the suitability of personal character are forming lifestyle (Hawkins, Mothersbaugh, \& Best, 2013). Furthermore, people who live in urban areas can be explained as social groups that are sociologically in the middle class, have a productive life, and are part of social change (Ansori, 2009). Based on research conducted by Suyanto, Sugihartati, Hidayat, \& Subiakto (2020) urban groups, especially those in the middle class, prefer to buy clothes online rather than buying at outlets, although the number of modern retails is more centered in urban areas such as Jakarta as a reflection of urban areas (Yulita, Simanjuntak, \& Sartono, 2019). Based on this it can be said that urban social groups have their own lifestyle in looking at the concept of buying a product / service. This is in line that lifestyle is related to factors such as how this group lives, spends money, and allocates time. (Mowen \& Minor, 2002). This group is not uncommonly influenced by individuals who fall into the category of millennial groups born between 1981 and 2000 (H. Lee, 2018). This is also reinforced by the fact that this group is more individualistic, especially in the benefits of using technology such as m-banking (Purwanto \& Loisa, 2020).
The Indonesian Internet Service Providers Association (AJII) published the results of the 2018 survey on Penetration \& Behavior Profiles of Indonesian Internet Users in which one of the data explained that Shopee was the most visited place to purchase goods/services online (APJII, 2019). Based on the survey (table 1) which field data was conducted in March-April 2019, Shopee succeeded in becoming the most frequently used (commercial) internet content of $11.2 \%$ followed by Bukalapak $(8.4 \%)$, Lazada (6.7\%), Tokopedia (4.3\%) and Blibli $(0.1 \%)$. This data can explain that consumers assume that Shopee is one of the favourite marketplaces for purchasing goods or services. Almost the same data is also published by Iprice insight, which periodically provides data on the number of monthly visitors. Shopee's position as a marketplace with the number of monthly visitors continues to increase throughout 2019 to 2020 . In the first 2019 (Q), the number of Shopee visitors was almost 75 million visitors per month and this made Shopee in the third position under Tokopedia and Bukalapak which reached 100 million visitors per month. Over time with the excellence and consistency of the services provided by Shopee, visitors to this marketplace continue to experience a significant increase where in Q2 2020, Shopee visitors have reached 93 million more visitors per month and succeeded in making Shopee the most frequently visited marketplace by consumers. Based on this data it can be explained that market share can increase or decrease along with shifting buyer tastes that can be influenced by several factors such as service consistency, user friendly technology, or promotional programs that attract buyers' interest.

Table 1. Number of Visitors to Online Stores in Indonesia 2019-2020 (in person) (Iprice insights, 2020)

\begin{tabular}{|c|c|c|c|c|c|c|}
\hline \multirow{2}{*}{$\begin{array}{c}\text { Online store } \\
\text { (Marketpalce) }\end{array}$} & \multicolumn{4}{|c|}{2019} & \multicolumn{2}{|c|}{2020} \\
\hline & Q1 & Q2 & Q3 & Q4 & Q1 & Q2 \\
\hline Tokopedia & 137.200 .900 & 140.414 .500 & $65,953,400$ & $72,973,300$ & $69,800,000$ & $86,103,300$ \\
\hline Bukalapak & 115.256 .600 & $89,765,800$ & $42,874,100$ & $39,263,300$ & $37,633,300$ & $35,288,100$ \\
\hline Shopee & 74.995 .300 & $90,705,300$ & $55,964,700$ & $67,900,000$ & $71,533,300$ & $93,440,300$ \\
\hline Lazada & 52.044 .500 & $49,620,200$ & $27,995,900$ & $28,383,300$ & $24,400,000$ & $22,021,800$ \\
\hline Blibli & 32.597 .200 & $38,453,000$ & $21,395,600$ & $26,863,300$ & $17,600,000$ & $18,307,500$ \\
\hline
\end{tabular}

The use of technology in self-service is an important factor to shape customer satisfaction (Anderson et al., 2013). Shopee as one of the marketplaces in Indonesia is enough to consider the factors of using the technology to continuously in the long run to get customer satisfaction. This marketplace allows users to make purchases with a variety of products (multi-product) available. Millennials in the region often make spontaneous purchases, so they often buy more than one product at a time. This is what underlies this research where the measurement of buyer behaviour, especially in the marketplace which is based on multi-product purchases needs to be reviewed again as previous studies do not explain multi-products in the purchasing decision process. Therefore, this study aims to analyse online buying behaviour in the "Shopee" marketplace with multi-product purchases.

\section{Technology Acceptance Model (TAM)}

Various studies on the Technology Acceptance Model (TAM) explain that this model is used to emphasize the association of several factors such as Perceived Ease of Use (PEOU), Perceived Usefulness (PU), Attitude Towards Using (ATU), and Actual System Usage (ASU) in technologybased matters (Ozturk, 2016; Lin, Lin, Yeh, \& Wang, 2016, Kaushik \& Rahman, 2015; Morosan, 2014). Online purchasing is one of the most researched topics especially in finding determinants that determine online purchases (Anesbury, Nenycz- 
Thiel, Dawes, \& Kenned Y, 2016; Ingham, Cadieux, \& Berrada, 2015; Lim \& Ting, 2014; Al- Qeisi, Dennis, Alamanos, \& Jayawardhena, 2014) both products and services. In the use of technology in online systems, various factors such as convenience, ease of use, speed of use also influence user satisfaction in searching for information or purchases. Basically, this research still adopts the TAM research model popularized by Davis with simplifications that are adapted to the use and character of this research.

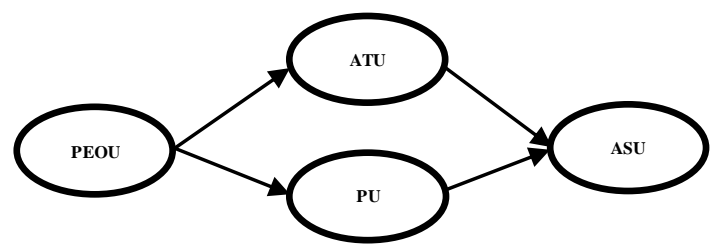

Figure 1. Research Model

Perceived Ease of Use is the level of ease in the use of a form of information technology. This level of ease of use can be influenced by several factors such as technological designs that are user friendly and easy to learn (Huang, Ho, Liu, \& Lin, 2015). Basically, Ease of Use affects the Attitude Toward Using (Behaviour of Use) (Huang et al., 2015). On the other hand, there are contradictions in research that have explained the role of the Ease of Use factor in the adoption of mobile commerce (Y. Lee, Park, Chung, \& Blakeney, 2011). Meanwhile there are studies such as Yadav, Sharma, \& Tarhini (2016) and Chong (2013) who found no influence. Based on this explanation, the hypothesis 1 in this study is as follows:

H1: Perceived Ease of Use has a significant effect on Attitude Toward Using

The site used as a medium for the delivery of product information and at the same time the purchasing process must be felt easily by users so that the ease of use factor in this case can be formed (Bauerová \& Klepek, 2018). The ease-of-use factor influences the shape of the usefulness of Gefen, Karahanna, \& Straub, 2003; Venkatesh, V., and Davis, 2000). This is also the same as research conducted by Rauniar, Rawski, Yang, \& Johnson (2014) where convenience must provide an element of benefit from the system used. Recent research conducted by Bauerová \& Klepek (2018) also explains that ease of use affects the factor of efficacy in terms of online purchasing. On the other hand, according to Huang et al. (2015) precisely Perceived Ease of Use has no effect on Perceived of Usefulness. Because of this, the next hypothesis in this study is:

H2: Perceived Ease of Use has a significant effect on Perceived of Usefulness
Attitude Toward Using or Behavior towards Usage is explained as the user's attitude because of the use of certain information technologies both positive and negative (Huang et al., 2015). The form of evaluating likes or dislikes can also explain the definition of Usage Behavior (Kanchanatanee, Suwanno, \& Jarernvongrayab, 2014). Evaluating the the likes or dislikes of usage also can be concluded as the result of actual system usage. The user's attitude does not affect the acceptance of information technology (Tyas \& Darma, 2017) where the use of the system is included in its scope. However, the attitude to use basically impacts the experience of using reality. Based on this the next hypothesis proposed is:

H3: Attitude Toward Using has a significant effect on Actual System Usage

Perceived of Usefulness or also known as the Benefit Factor popularized by Davis can be explained as a factor of usefulness or usefulness of an information technology that can improve the efficiency and performance felt by users (Huang et al., 2015). In connection with online purchases, the use of the system will benefit users (Bauerová \& Klepek, 2018). Several studies have proven that the Benefit Factor has a significant influence on the use of mobile commerce (Yadav, Sharma, \& Tarhini, 2016; Hanafizadeh, Behboudi, Koshksaray, \& Tabar, 2014; Sharma \& Govindaluri, 2014; Chong, 2013). Other studies have revealed that the Benefit Factor does not affect Actual System Usage (Tyas \& Darma, 2017). Therefore, the following hypothesis is proposed:

H4: Perceived of Usefulness has a significant effect on Actual System Usage 


\section{METHODS}

\section{Location of Study}

As one of the urban areas with the largest population in Indonesia, Jakarta was chosen to be the research location. The data in this study were taken using a questionnaire as an instrument with a Likert scale of 1-5 as a measurement scale for its assessment in the range of its disapproval to the approval (Malhotra, Birks, \& Wills, 2012). The sample in this study is the millennial group in Jakarta who has experience buying multi-products at Shopee within this year. The number of samples in this study is as much as 163. In determining the number of samples used in this study can be done by multiplying the number of indicators by 5 to 10 (Hair, Black, \& Babin, 2010). Data is collected from March to July 2020.

\section{Data Analysis}

In data analysis, this quantitative research uses SMART PLS 3.0. In the analysis carried out a series of tests, namely the validity, reliability, determination, and hypothesis testing. The research model consists of four variables (variables) namely Perceived Ease of Use, Attitude Toward Using, Perceived of Usefulness, Attitude Toward Using, and Actual System Usage. Perceived Ease of Use consists of six items while Perceived of Usefulness has eight items. Next Attitude Toward Using consists of three items and there are five items in the Actual System Usage. As an initial screening, respondents were asked whether they had experience buying multi-products in a single purchase process. This is to get a balanced assessment of the characteristics of the respondents' experience.

\section{RESULTS AND DISCUSSION}

Based on available data, there are 94 male respondents or $57.67 \%$, while the number of female respondents is 69 people or $42.33 \%$. These results explain that in this study dominated by male respondents. Furthermore, from the devices used in making online purchases at Shopee, 22 respondents or $13.5 \%$ used Personal Computer / Laptop devices while 141 respondents or $86.5 \%$ used smartphone devices. This explains that millennial behavior in the Jakarta area prefers to use mobile devices to make online purchases.

\section{Validity and Reliability Test}

In the first testing process, there were several items (PEOU5, PEOU6, ASU2) that did not meet the requirements because the numbers on the outer loadings were below 0.7 so they had to be discarded. After the second process the numbers of all items in the outer loadings are above 0.7 . These results explain that all items meet the validity requirements. In Average Variance Extracted (AVE), all variables are above 0.5 (PEOU $=0.656$; $\mathrm{PU}=0.641$; ATU $=$ $0.842 ; \mathrm{ASU}=0.700$ ) which explains that all variables are said to be valid.

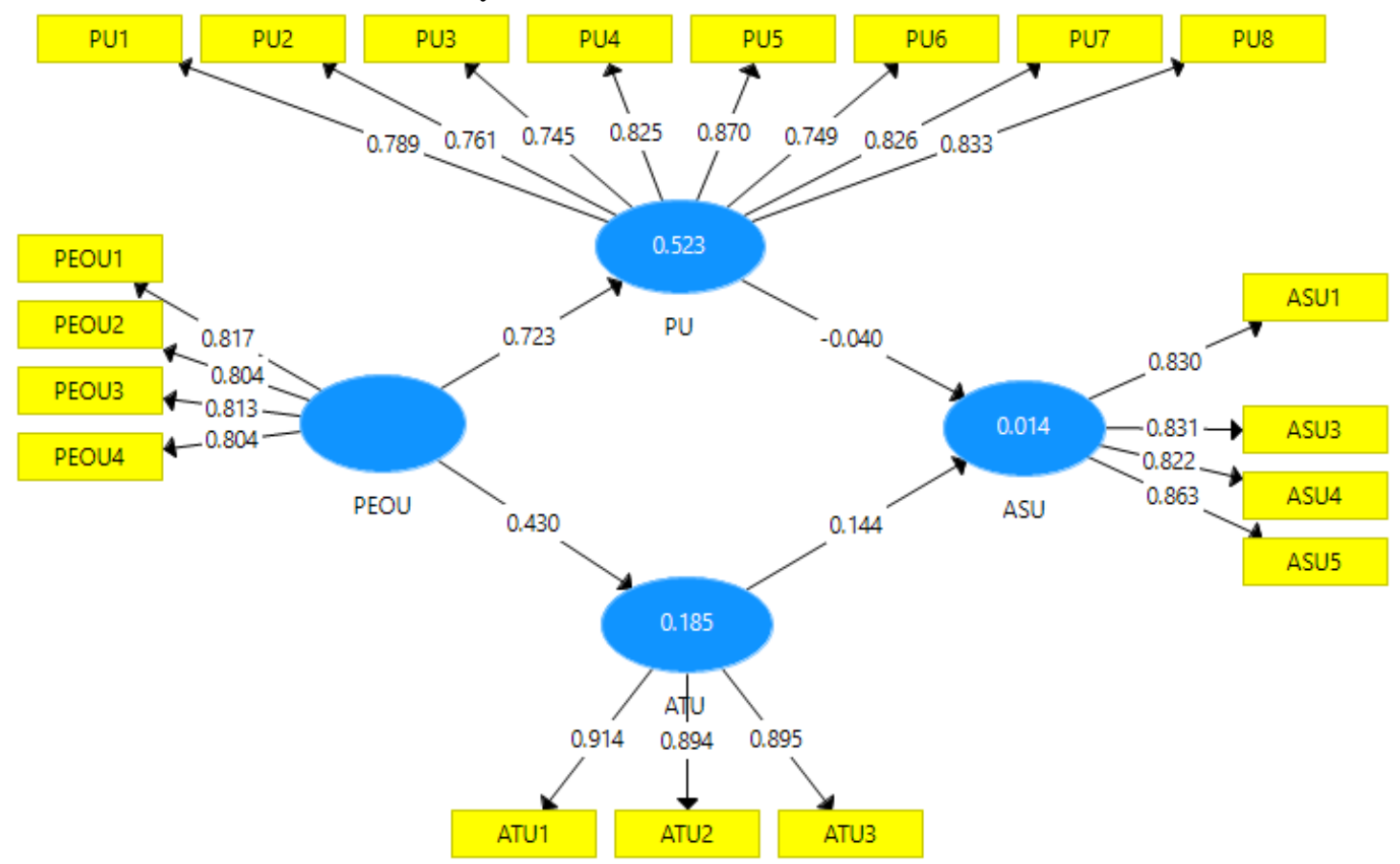

Figure 2. Outer Loadings, Source: SMART PLS 3.0; $\mathrm{n}=-163$

Meanwhile, the numbers on Cronbach's Alpha for all variables show numbers above 0.7 . This result explains that all variables are reliable. Furthermore, from the Composite Reliability results, all the numbers show numbers above 0.7. These results explain that all variables in this study can be said to be reliable. 
Table 2. Reliability Test (Source: SMART PLS 3.0; n=-163)

\begin{tabular}{ccc}
\hline & Cronbach's Alpha & Composite Reliability \\
PEOU & 0,850 & 0,884 \\
PU & 0,920 & 0,935 \\
ATU & 0,884 & 0,928 \\
ASU & 0,857 & 0,903 \\
\hline
\end{tabular}

The R-Square results explain the coefficient of determination in this study. The result of R-Square PU is 0.523 . This figure explains that the Benefit Factor is influenced by the Ease of Use factor of $52.3 \%$ and the rest is influenced by other factors. Furthermore, the results on ATU have a figure of 0.185 . This figure explains that Usage Behaviour is influenced by the Ease of Use factor of $18.5 \%$. Then the number in ASU shows a value of 0.014 which explains that the use of reality is influenced by the Benefit and Behaviour factors of Usage by $1.4 \%$ while the remaining $98.6 \%$ is influenced by other factors outside this study.

\section{Hypothesis testing}

Hypothesis testing can be explained in the following table. In the table below PEOU $\rightarrow$ ATU shows a figure of 7,007. This figure is above 1.96 which explains that the Usage Behaviour Factor is influenced by the Ease of Use Factor. Therefore, it can be said that $\mathrm{H} 1$ was accepted. Behaviour in making online purchases at Shopee in the millennial group is determined by the Ease of using this marketplace site. Shopee which has two views, both desktop view (via a computer screen) and apps view (via an application in the device) must have the same navigation, search, and so on capabilities in both views. Remarkably diverse features become important considerations for companies to pay attention to user comfort, so they always feel easy (not difficult). What is more when a user decides to make a multi-product purchase in a single purchase. "Stock / basket" settings are taken into consideration when the user does each process. The results of this study are in line with research conducted by Huang et al., (2015) and Y. Lee et al., (2011). But on the other hand, this study is not in line with research conducted by Yadav et al., (2016).

Furthermore, the PEOU $\rightarrow$ PU shows the number 29.482 which is above 1.96. These results explain that the Benefit Factor is influenced by the Ease of Use Factor. Based on these results it can be explained that $\mathrm{H} 2$ was received. The results of this study are directly proportional to the study conducted by Bauerová \& Klepek (2018), Rauniar et al. (2014), Gefen et al. (2003), (Venkatesh, V., \& Davis, 2000), However the results of this study are inversely proportional to the research of Huang et al. (2015). The Benefit Factor that is felt by users in using Shopee's website or application is based on the Ease of Use Factor. Perceived difficulties will create negative experiences or forms of stress (Christian, Purwanto, \& Wibowo, 2020) for users so that the element of expediency cannot be obtained by users and it is feared that loyalty is not formed.

Table 3. Uji Hipotesis (Source: SMART PLS 3.0; $n=-163$ )

\begin{tabular}{ccc}
\hline & T-Statistics $(|\mathbf{O} / \mathbf{S T D E V}|)$ & Result \\
PEOU $\rightarrow$ ATU & 7,007 & H1 accepted \\
PEOU $\rightarrow$ PU & 29,482 & H2 accepted \\
ATU $\rightarrow$ ASU & 1,180 & H3 rejected \\
PU $\rightarrow$ ASU & 0,305 & H4 rejected \\
\hline
\end{tabular}

ATU $\rightarrow$ ASU shows a figure of 1,180. These results explain that $\mathrm{H} 3$ is rejected because the $\mathrm{t}$ statistic number is below 1.96. This result explains that usage is not influenced by usage behavior factor. Shopee users especially millennials feel that Usage is not determined by Usage Behavior. This is indicated that users will be easily influenced by factors such as discounts, attractive appearance, and variety of products they like. Similarly, advertisements ignored by millennial audiences are caused by advertisement clutter so initial expectations are not formed (Christian, 2019b). Therefore, usage behavior in the millennial group is dynamic so that satisfaction is not constant in forming loyalty. The results of this study support research conducted by Tyas \& Darma, (2017) but do not support research conducted by Huang et al., (2015).

In the last hypothesis PU $\rightarrow$ ASU shows a figure of 0.305 which is below 1.96. This figure explains that the usage is not influenced by the benefits provided. The Benefit Factor greatly impacts the Use of Shopee as a marketplace. Satisfaction and loyalty that is formed is determined by the sense of benefits obtained by the user. However, the use of technology influences the success of a company's performance (Christian, 2019a) such as Shopee. Based on this result, this study supports the study of Tyas \& Darma (2017), but on the different side this study rejects research conducted by Bauerová \& Klepek (2018), Yadav et al., (2016), Huang et al., (2015), Hanafizadeh et al. 
(2014), Sharma \& Govindaluri (2014), (Chong, 2013).

\section{CONCLUSSION}

Based on the results and discussion above, the results of this study can be concluded that Hypothesis 1 is accepted which explains the Usage Behaviour Factor influenced by the Ease of Use Factor. Hypothesis 2 in this study was also accepted where the Benefit Factor was influenced by the Ease of Use Factor. Instead the two hypotheses show different results. Hypothesis 3 in this study explains that Usage is not influenced by Behavioural Use factors. Furthermore, Hypothesis 4 in this study explains the use is not influenced by the benefits provided. The use of the Technology Acceptance Model (TAM) model based on these results can indeed still be used in explaining the shift in behaviour of using a form of marketplace, especially in making multi-product purchases. Diverse user characteristics according to the generation group still needs to be studied to provide a deeper understanding. This is useful for companies to be able to detect and get solutions to any phenomena that occur especially early that are related to user satisfaction and loyalty in using a marketplace.

\section{REFERENCES}

Al-Qeisi, K., Dennis, C., Alamanos, E., \& Jayawardhena, C. (2014). Website design quality and usage behavior: Unified Theory of Acceptance and Use of Technology. Journal of Business Research, 67(11), pp. 2282-2290.

Anderson, L., Ostrom, A. ., Corus, C., Fisk, R. ., Gallan, A..,Girado, M., Williams, J. (2013). Transformative service research: an agenda for the future. Journal of Business Research, 66(8), pp. 1203-1210.

Anesbury, Z., Nenycz-Thiel, M., Dawes, J., \& Kennedy, R. (2016). How Do Shoppers Behave Online? An observational study of online grocery shopping. Journal of Consumer Behaviour, 3(15), pp. 261270.

Ansori, M. H. (2009). Consumerism and the Emergence of a New Middle Class in Globalizing Indonesia. Explorations: A Graduate Student Journal of Southeast Asian Studies, 9(1), pp. 87-97.

APJII. (2019). Hasil Survei Penetrasi dan Perilaku Pengguna Internet Indonesia 2018. Retrieved July 26, 2020, from Asosiasi Penyelenggara Jasa Internet Indonesia website: https://apjii.or.id/survei

Bauerová, R., \& Klepek, M. (2018). Technology Acceptance As A Determinant Of Online Grocery Shopping Adoption. Acta Universitatis Agriculturae Et Silviculturae Mendelianae Brunensis, 66(76), pp. 737-746. https://doi.org/10.11118/actaun201866030737

Chong, A. Y. . (2013). Predicting m-commerce adoption determinants: a neural network approach. Expert Systems with Applications, 40(2), pp. 523-530.

Christian, M. (2019a). Dampak Penggunaan Teknologi Berbasis Aplikasi Pada Usaha Restoran Berskala Mikro \& Kecil. Journal of Business and Applied Management, 12(2), pp. 132-198.
Christian, M. (2019b). Telaah Keniscayaan Iklan Di Kanal Youtube Sebagai Perilaku Khalayak Di Kalangan Milenial (Study The Inevatibility of Advertisements on Youtube Channels as Audience Behavior among Milennials). Bricolage: Jurnal Magister Ilmu Komunikasi, 5(2), pp. 141-158.

Christian, M., Purwanto, E., \& Wibowo, S. (2020). Technostress Creators on Teaching Performance of Private Universities in Jakarta During Covid-19 Pandemic. Technology Reports of Kansai University, 62(6), pp. 2799-2809.

Gefen, D., Karahanna, E., \& Straub, D. W. (2003). Trust and TAM in Online Shopping: An Integrated Model. MIS Quarterly, 27(1), pp. 51-90.

Hair, J. F., Black, W. C., \& Babin, B. J. (2010). Multivariate Data Analysis (7th ed.). New Jersey: Pearson Prentice Hall.

Hanafizadeh, A., Behboudi, M., Koshksaray, A. ., \& Tabar, M. J. . (2014). Mobile-banking adoption by Iranian bank clients. Telematics and Informatics, 31(1), pp. 62-78.

Hawkins, D. I., Mothersbaugh, D., \& Best, R. . (2013). Consumer Behavior: Building Marketing Strategy. New York: Mcgraw-Hill.

Huang, J.-M., Ho, T.-K., Liu, Y.-C., \& Lin, Y.-H. (2015). A discussion on the user intention of golfers toward golf GPS navigation. Journal of Hospitality and Tourism Technology, 6(1), pp. 26-39.

Ingham, J., Cadieux, J., \& Berrada, A. (2015). e-Shopping acceptance: A qualitative and meta-analytic review. Information \& Management, 52(1), pp. 44-60.

Ipriceinsights. (2020). Peta E-Commerce Indonesia. Retrieved July 26, 2020, from iprice.co.id website: https://iprice.co.id/insights/mapofecommerce/

Jati, W. R. (2015). Less Cash Society: Menakar mode konsumerisme kelas menengah Indonesia. Sosioteknologi, 14(2), pp. 102-112.

Kanchanatanee, K., Suwanno, N., \& Jarernvongrayab, A. (2014). Effects Of Attitude Toward Using, Perceived Usefulness, Perceived Ease Of Use And Perceived Compatibility On Intention To Use EMarketing. Journal of Management Research.

Kaushik, A. ., \& Rahman, Z. (2015). An alternative model of self-service retail technology adoption. Journal of Services Marketing, 29(5), pp. 406-420.

Lee, H. (2018). Are Millennials Coming to Town? Residential Location Choice of Young Adults. Urban Affairs Review, pp. 1-40.

Lee, Y. ., Park, J. ., Chung, N., \& Blakeney, A. (2011). A unified perspective on the factors influencing usage intention towards mobile financial services. Journal of Business Research, 65(11), pp. 15901599.

Lim, W. ., \& Ting, D. . (2014). Consumer Acceptance and Continuance of Online Group Buying. Journal of Computer Information Systems, 54(3), pp. 87-96.

Lin, H.-H., Lin, S., Yeh, C.-H., \& Wang, Y.-S. (2016). Measuring mobile learning readiness: scale development and validation. Internet Research, 26(1), pp. 265-287.

Malhotra, N. ., Birks, D. ., \& Wills, P. (2012). Marketing Research: An Applied Approach (4th editio). Harlow: Pearson Education.

Morosan, C. (2014). Towards an integrated model of adoption of mobile phones for purchasing ancillary services in air travel. International Journal of Contemporary Hospitality Management, 26(2), pp. 
246-271.

Mowen, J. C., \& Minor, M. (2002). Consumer Behaviour. Upper Saddle River: Prentice Hall. Inc.

Ozturk, A. . (2016). Customer acceptance of cashless payment systems in the hospitality industry. International Journal of Contemporary Hospitality Management, 28(4).

Purwanto, E., \& Loisa, J. (2020). The Intention and Use Behaviour of the Mobile Banking System in indonesia: UTAUT Model. Technology Reports of Kansai University, 62(06), pp. 2757-2767.

Rauniar, R., Rawski, G., Yang, J., \& Johnson, B. (2014). Technology acceptance model (TAM) and social media usage: an empirical study on Facebook. Journal of Enterprise Information Management, 27(1), pp. 6-30.

Sharma, S. ., \& Govindaluri, S. . (2014). Internet banking adoption in India: structural equation modeling approach. Journal of Indian Business Research, 6(2), pp. 155-169.

Singh, S., Kumar, S., Goel, T., \& Chawla, S. (2014). Impact of Brand on Rural and Urban Consumer Behavior A Study on Mobile Phone Buyers. IOSR Journal of Business and Management (IOSR-JBM), 16(5), pp. 73-78.

Suyanto, B., Sugihartati, R., Hidayat, M., \& Subiakto, H. (2020). Global vs. local: lifestyle and consumption behaviour among the urban middle class in East Java, Indonesia. South East Asia Research, 27(4), pp. 398-417.

Tyas, E. I., \& Darma, E. S. (2017). Pengaruh Perceived Usefulness, Perceived Ease of Use, Perceived Enjoyment, dan Actual Usage Terhadap Penerimaan Teknologi Informasi: Studi Empiris Pada Karyawan Bagian Akuntansi dan Keuangan Baitul Maal Wa Tamwil Wilayah Daerah Istimewa Yogyakarta dan Sek. Reviu Akuntansi Dan Bisnis Indonesia, 1(1), pp. 25-35.

Venkatesh, V., dan Davis, F. . (2000). A Theoretical Extension of the Technology Acceptance Model : Four Longitudinal Field Studies. Management Science, 46(2), pp. 186-204.

Yadav, R., Sharma, S. ., \& Tarhini, A. (2016). A multianalytical approach to understand and predict the mobile commerce adoption. Journal of Enterprise Information Management, 29(2), pp. 222-237.

Yulita, F. H., Simanjuntak, M., \& Sartono, B. (2019). Shopping Behavior Of Indonesian Customer In Modern Retail. Russian Journal of Agricultural and Socio- Economic Sciences, 4(88), pp. 95-101. 